\title{
Effect of barley straw and Egyptian clover hay on the rumen fermentation and structure and fibrolytic activities of rumen bacteria in dromedary camel
}

\author{
Alaa Emara Rabee $\mathbb{D}$ \\ Department of Animal and Poultry Nutrition, Desert Research Center, Cairo, Egypt. \\ Corresponding author: Alaa Emara Rabee, e-mail: rabee_a_m@yahoo.com \\ Received: 28-09-2021, Accepted: 17-12-2021, Published online: 17-01-2022
}

doi: www.doi.org/10.14202/vetworld.2022.35-45 How to cite this article: Rabee AE (2022) Effect of barley straw and Egyptian clover hay on the rumen fermentation and structure and fibrolytic activities of rumen bacteria in dromedary camel, Veterinary World, 15(1): 35-45.

\begin{abstract}
Background and Aim: Understanding the regulations of rumen microbiota and their fibrolytic capabilities under different forages are essential to improve rumen fermentation and animal feed efficiency. This study aimed to evaluate the changes in the rumen fermentation and the structure and fibrolytic activities of rumen bacteria in camels fed barley straw and Egyptian clover hay.

Materials and Methods: Three fistulated camels were fed a diet containing barley straw for 30 days; then transitioned to a diet containing Egyptian clover hay for 30 days. In addition, bacterial media enriched with xylan and different cellulose sources, namely, filter paper, wheat straw, and alfalfa hay, were used to evaluate the ability of camel rumen bacteria to produce xylanase and cellulase enzymes.

Results: The camel group fed Egyptian clover hay showed higher crude protein intake, rumen ammonia, total volatile fatty acids, and acetic acid. Moreover, the camel group fed barley straw showed higher neutral detergent fiber intake, rumen $\mathrm{pH}$, and propionic and butyric acids. Principal component analysis showed that bacterial communities were separated based on the forage type. Forage type affected the composition of rumen bacteria and most of the bacterial community was assigned to phylum Bacteroidetes and Firmicutes. Egyptian clover hay diet increased the proportions of genus Prevotella and Ruminococcus; while fed barley straw diet increased the Butyrivibrio, RC9 gut group, and Fibrobacteres. The bacterial culture of the Egyptian clover hay fed group produced the greatest xylanase and the bacterial culture of the barley straw fed group produced the maximum cellulase.
\end{abstract}

Conclusion: Egyptian clover hay is recommended to feed camels in intensive production. Moreover, the bacterial community in the camel rumen is a promising source of lignocellulolytic enzymes.

Keywords: Camelus dromedaries, cellulase and xylanase, forage type, hay and straw, rumen bacteria.

\section{Introduction}

Dromedary camel can withstand the adverse conditions of hot deserts due to its adaptability to heat stress, severe droughts [1], and it can utilize poor-quality fodder plants that are avoided by other herbivores [2]. Moreover, it can provide more meat and milk than other animals under harsh desert conditions [3]. Therefore, the camel is a key player animal in food security in drought regions [4]. Consequently, the camel farming system is changing from the pastoral system to the intensive system [5], and camel feeding is shifting from grazing in pastoral areas to concentrated supplements and high-quality forages in intensive farms $[6,7]$. Camel feeding and management for intensive meat and milk production need to be studied sufficiently to exploit the potential of the camel as a source of animal protein [7-10]. Dietary forage is important for rumen health and stability of the rumen ecosystem

Copyright: Rabee. Open Access. This article is distributed under the terms of the Creative Commons Attribution 4.0 International License (http://creativecommons.org/licenses/by/4.0/), which permits unrestricted use, distribution, and reproduction in any medium, provided you give appropriate credit to the original author(s) and the source, provide a link to the Creative Commons license, and indicate if changes were made. The Creative Commons Public Domain Dedication waiver (http://creativecommons.org/ publicdomain/zero/1.0/) applies to the data made available in this article, unless otherwise stated. and affects the feed intake [11]. Farid et al. [9] indicated that camels fed different types of forage showed different average daily gains. Egyptian clover and straw of cereal crops are commonly used in animal feeding in Egypt [12]. Furthermore, the deficiency of high-quality forage such as alfalfa and Egyptian clover hay is the driving force to use low-quality forage such as crop straw in animal feeding $[3,13]$.

The digestion of plant biomass in the rumen relies on the activities of symbiotic microorganisms, including bacteria, protozoa, fungi, and archaea, that convert feedstuff to volatile fatty acids (VFAs) and microbial protein that provide the host animal with energy and protein $[14,15]$. Rumen bacteria predominate the rumen microbiota and degrade a wide range of substrates, including protein, lipids, and a wide range of polysaccharides such as cellulose, hemicellulose, pectin, and starch $[7,16]$. Therefore, the abundance of rumen bacteria is primarily affected by the chemical composition of animal diet [17]. Subsequently, it is necessary to understand the changes in rumen fermentation and modulations of rumen bacteria under different feeding systems to create efficient and stable microbial communities, which optimally degrade ingested feeds and maximize animal productivity $[18,19]$. The rapid expansion of molecular techniques such 
as next-generation sequencing has enabled determining the changes in rumen microbiota under various treatment conditions, which offer the possibility to improve the digestibility of plant fiber and improve animal productivity [7]. A previous study suggested that the microbial community in camel can degrade poor-quality plant biomass [20-22]. Thus, the camel rumen microbiome could be a promising source of carbohydrate-active enzymes used in different biotechnological and industrial applications [21]. Some rumen bacteria were used to produce fibrolytic enzymes, including Rumminococcus, Bacillus, and Clostridium [23-25]. Therefore, camel rumen could be a promising enzyme source with commercial applications [21]. Cellulase and xylanase enzymes have a key role in feed additives manufacturing and the bioconversion of lignocellulosic biomass to animal feed or fermentable sugars for biofuel production [24,26-28]. Therefore, the demand for cheap and high active, and stable enzymes is growing rapidly $[21,26]$.

Most of the studies conducted on rumen microbiota in dromedary camels $[3,7,29]$ are surveys. Moreover, intensification of camel production is the main driver to study the effect of different diet types on performance and rumen fermentation to optimize animal productivity. Little information is available regarding the effect of forage type on the rumen fermentation and composition and fibrolytic activities of rumen bacteria in camel; Hinsu et al. [22] investigated the effect of diets differing in the forage source, Pennisetum glaucum, Sorghum bicolor, and Zea mays, on camel rumen bacteria. However, no studies determined the effect of Egyptian clover hay and barley straw on camel rumen bacteria and their fibrolytic activities.

This study aimed to evaluate the changes in the rumen fermentation as well as the structure and fibrolytic activities of rumen bacteria in camels fed barley straw and Egyptian clover hay. Furthermore, the ability of rumen bacteria to produce lignocellulolytic enzymes using different carbon sources was evaluated.

\section{Materials and Methods}

\section{Ethical approval}

The study was conducted under the guidelines of the Department of Animal and Poultry Production, Desert Research Center, Egypt. In addition, the study was approved by the Institutional Animal Care and Use Committee, Faculty of Veterinary Medicine, University of Sadat City (Approval number: VUSC00008). All methods were performed in compliance with the ARRIVE guidelines.

\section{Study period and location}

The study was conducted from July to August 2019 (60 days) at Maryout Research Station, Desert Research Center, Alexandria, Egypt.

\section{Animals}

Three fistulated camels with an average body weight of $455 \mathrm{~kg}$ were used in this study. Throughout the experiment, animals were offered two experimental diets different in forage type. Concentrate feed mixture (CFM) was offered at $1400 \mathrm{~g} /$ head and roughage was provided to all animals ad libitum. In the first experimental period, barley straw (Hordeum vulgare) was provided as sole roughage. Then, the animals were transitioned to the second experimental diet with the same concentrates mixture plus Egyptian clover hay (Trifolium alexandrinum) as sole roughage. Animals were fed every diet for 30 days before the sampling period. Feed intake was determined for every animal. Concentrate feed mixture consisted of corn $57.5 \%$, soybean meal $23 \%$, wheat bran $19 \%$, limestone $2.5 \%$, salt $1.5 \%$, sodium bicarbonate $0.5 \%$, premix $0.4 \%$, and antitoxins $0.1 \%$. The chemical analysis of barley straw, Egyptian clover hay, and CFMs are presented in Table-1.

\section{Rumen samples and fermentation parameters}

At the end of the adaptation period of 30 days, rumen contents were collected before feeding and strained by two layers of cheesecloth. The $\mathrm{pH}$ of rumen samples was recorded using a digital $\mathrm{pH}$ meter (WPA CD70, ADWA, Szeged, Hungary). The rumen liquor was used to analyze rumen ammonia- $\mathrm{N}\left(\mathrm{NH}_{3}-\mathrm{N}\right)$ and total VFA, DNA isolation, and inoculation of rumen bacteria into cellulolytic and xylanolytic media to determine the production of cellulase and xylanase.

\section{Chemical analysis}

Dry matter (DM) and crude protein (CP) of the experimental diets were analyzed according to the Association of Official Analytical Chemists (AOAC) [30]. Neutral detergent fiber (NDF) was determined according to Van Soest et al. [31] without sodium sulfite. Rumen ammonia and total VFA were determined according to the methods of Annison [30] and AOAC [32], respectively. In addition, individual VFAs were measured using high-performance liquid chromatography.

\section{Bacterial community analysis \\ DNA extraction, polymerase chain reaction (PCR) amplification, and sequencing}

One milliliter of rumen sample was centrifuged at $14,000 \times g$. The remaining pellets were used for DNA extraction by i-genomic Stool DNA Extraction

Table-1: The chemical composition (\%) of concentrates feed mixture, barley straw, and Egyptian clover hay.

\begin{tabular}{lcccc}
\hline Item & Dry matter & Ether extract & Crude protein & Neutral detergent fiber \\
\hline Barely straw & 88 & 3.1 & 4.75 & 67 \\
Egyptian clover hay & 89 & 2.65 & 13.03 & 50 \\
Concentrate feed mixture & 90 & 4.5 & 14.5 & 53 \\
\hline
\end{tabular}


Mini Kit (iNtRON Biotechnology, Inc., Korea) according to the manufacturer's instructions. DNA was eluted in $50 \mu \mathrm{L}$ elution buffer, and DNA quantity and quality were checked by agarose gel electrophoresis and nanodrop spectrophotometer (Thermo Fisher Scientific, Madison, Wisconsin, USA). The V4 region of the bacterial $16 \mathrm{~S}$ ribosomal DNA gene was amplified using primers 515F and 926R [33]. PCR amplification was conducted under the following conditions: $94^{\circ} \mathrm{C}$ for $3 \mathrm{~min}$; 35 cycles of $94^{\circ} \mathrm{C}$ for $45 \mathrm{~s}, 50^{\circ} \mathrm{C}$ for $60 \mathrm{~s}$, and $72^{\circ} \mathrm{C}$ for $90 \mathrm{~s}$; and $72^{\circ} \mathrm{C}$ for $10 \mathrm{~min}$. PCR products purification and preparation for sequencing using Illumina MiSeq system were conducted according to the protocol described by Comeau et al. [34] in Integrated Microbiome Resource (Dalhousie University, Canada).

\section{Determination of copy number of bacterial 16S rRNA by quantitative PCR (qPCR)}

Quantitative real-time PCR (qPCR) was used to determine the total bacterial 16S rRNA copy number in the rumen samples. Standards were generated using serial dilutions of DNA purified from Prevotella spp., Ruminococcus albus, and Butyrivibrio hungatei that were purchased from DSMZ (Braunschweig, Germany). Serial dilutions of the standards ranging from $10^{1}$ to $10^{6}$ copies of the $16 \mathrm{~S}$ rRNA gene were used. The qPCR was performed using the Applied Biosystems StepOne system (Applied Biosystems, Foster City, USA). Bacterial primers F (5'-CGGCAACGAGCGCAACCC-3') and R (5'-CCATTGTAGCACGTGTGTAGCC-3') [35] were applied. The $10 \mu \mathrm{L}$ reaction consisted of $1 \mu \mathrm{L}$ genomic DNA, $1 \mu \mathrm{L}$ of each primer, and $7 \mu \mathrm{L}$ SYBER Green qPCR Master Mix (iNtRON Biotechnology, Inc.). The PCR conditions followed 40 cycles of $95^{\circ} \mathrm{C}$ for $15 \mathrm{~s}$ and $60^{\circ} \mathrm{C}$ for $60 \mathrm{~s}$. The linear relationship between the threshold amplification (cycle threshold) and the logarithm of $16 \mathrm{~S}$ rDNA copy numbers of the standards was used to calculate the copy numbers of rumen bacteria per $\mu \mathrm{L}$ of DNA.

\section{Bioinformatics analysis}

All the paired-end Illumina raw sequence reads were processed in $\mathrm{R}$ (version 3.5.2) using the DADA2 (version 1.11.3) pipeline as described by Callahan et al. [36]. First, quality checks were conducted; clean reads were denoised, dereplicated, and filtered for chimeras to generate amplicon sequence variants (ASVs). Taxonomic assignment of sequence variants was performed using a combination of the functions assign Taxonomy and assignSpecies and was compared using the SILVA reference database.

\section{Cultivation of anaerobic rumen bacteria}

The growth medium was the modification of medium 10 [37]. The composition of the growth medium was as follows (per $1000 \mathrm{~mL}$ distilled water): $2 \mathrm{~g}$ trypticase, 0.5 gyeast extract, $37 \mathrm{~mL}$ solution of $\mathrm{K}_{2} \mathrm{HPO}_{4} \cdot 3 \mathrm{H}_{2} \mathrm{O}$ ( $0.6 \mathrm{~g}$ in $100 \mathrm{~mL}$ distilled $\mathrm{H}_{2} \mathrm{O}$ ), $37 \mathrm{~mL}$ salt solution $\left[0.16 \mathrm{~g} \mathrm{CaCl}_{2} \cdot 2 \mathrm{H}_{2} \mathrm{O}, 0.6 \mathrm{~g} \mathrm{KH}_{2} \mathrm{PO}_{4}, 1.2 \mathrm{~g} \mathrm{NaCl}, 0.6 \mathrm{~g}\right.$
$\left(\mathrm{NH}_{4}\right)_{2} \mathrm{SO}_{4}, 0.25 \mathrm{~g} \mathrm{MgSO}_{4} \cdot 7 \mathrm{H}_{2} \mathrm{O}$ in $100 \mathrm{~mL}$ distilled $\left.\mathrm{H}_{2} \mathrm{O}\right], 1 \mathrm{~mL}$ Hemin solution $\left(1 \mathrm{~g} \mathrm{~L}^{-1}\right), 1 \mathrm{~mL}$ Resazurin solution $\left(1 \mathrm{~g} \mathrm{~L}^{-1}\right), 50 \mathrm{~mL}$ solution of $\mathrm{Na}_{2} \mathrm{CO}_{3}(8 \mathrm{~g}$ in 100 distilled $\mathrm{H}_{2} \mathrm{O}$ ), $1 \mathrm{~g}$ L-cysteine $\mathrm{HCl}, 200 \mathrm{~mL}$ clarified rumen fluid, $1 \mathrm{~mL}$ vitamin mix, and $1 \mathrm{~mL}$ trace mineral solution that was described by McSweeney et al. [38]. Rumen fluid was clarified and an anaerobic medium was prepared according to McSweeney et al. [38]. To determine the xylanolytic activities of camel rumen bacteria, the growth medium was supplemented with birchwood xylan (100 mg/bottle) (X). To determine the cellulolytic activities, the growth media were supplemented with one of the three fiber sources, filter paper (FP) (2 disks/bottle), wheat straw (WS) (100 mg/bottle), and alfalfa hay $(\mathrm{AH})(100 \mathrm{mg} /$ bottle $)$. The medium $\mathrm{pH}$ was adjusted at 6.8 and about $50 \mathrm{~mL}$ of media was tubed into $120 \mathrm{~mL}$ serum bottles under the steam of $\mathrm{CO}_{2}$; then, the bottles were sealed and autoclaved at $121^{\circ} \mathrm{C}$ for $15 \mathrm{~min}$. Strained rumen samples from each animal were kept under the stream of $\mathrm{CO}_{2}$; then, $1 \mathrm{~m}$ of every rumen sample was inoculated into every serum bottle and two bottles were prepared for every sample for four media (X, FP, WS, and AH). Rumen bacteria were grown anaerobically at $39^{\circ} \mathrm{C}$ for 2 days.

\section{Cellulase and xylanase enzyme assay}

Samples of growing bacteria were collected and centrifuged at $13,000 \times \mathrm{g}, 15 \mathrm{~min}, 4^{\circ} \mathrm{C}$ and the supernatant was used for enzyme assays. Cellulase and xylanase activities $(\mathrm{mU} / \mathrm{mL})$ were measured using EnzChek cellulase substrate (Invitrogen, UK) that determines endo1,4- $\beta$-glucanase and EnzChek Ultra Xylanase Assay Kit (Invitrogen) that determines endo-1,4- $\beta$-xylanase, according to the manufacturer recommendations.

\section{Statistical analysis}

The statistical analyses were conducted using the IBM Statistical Package for the Social Sciences (SPSS) version 20 software (IBM Corp., NY, USA) [39] and PAST [40]. The differences in feed intake, rumen fermentation parameters, bacterial copy number, microbial diversity, the relative abundance of bacterial phyla and genera, and cellulase and xylanase productions were performed using unpaired t-test. Principal component analysis was performed using the data of the relative abundance of dominant bacterial genera, the values of alpha diversity metrics, rumen fermentation parameters, and enzyme activities. All the sequences were deposited to the Sequence Read Archive, NCBI, under the accession number: PRJNA743427.

\section{Results}

\section{Chemical composition}

The chemical compositions on DM basis of CFM, barley straw, and Egyptian clover hay are shown in Table- 1 . The results revealed that $\mathrm{CP}$ content was higher in CFM (14.5\%) and clover hay (13.03\%) compared to barley straw (4.75\%). In contrast, barley straw showed higher NDF (67\%) compared to CFM $(53 \%)$ and Egyptian clover hay (50\%). 


\section{Feed intake and rumen fermentation}

The results revealed that all animals consumed all the offered CFM. The results of total and roughage feed intake expressed as $\mathrm{g} / \mathrm{kg}^{0.75}$ (kilogram metabolic body weight) are shown in Table-2. The results revealed that DM intake (DMI) was similar between the experimental groups. Meanwhile, the forage type affected the CP intake (CPI) and NDF intake (NDFI) significantly $(p<0.05)$. The camel group fed Egyptian clover hay showed significantly higher CPI; while the camel group fed barley straw showed higher NDFI.

Table-3 illustrates the effect of forage type on the rumen $\mathrm{pH}$, ammonia, total VFA, VFA fraction, and bacterial population. The results revealed that rumen $\mathrm{pH}$ was significantly higher $(\mathrm{p}<0.05)$ in the camel group who received barley straw; and the camel group who received Egyptian clover hay revealed higher ammonia $(\mathrm{p}<0.05)$ and total VFA $(p<0.05)$. Furthermore, the results revealed that the camel group fed Egyptian clover hay had higher acetic acid concentration, while the group fed barley straw showed higher propionic and butyric acids concentrations without significant differences. Moreover, the camel group fed barley straw showed a higher rumen bacterial population $(\mathrm{p}<0.05)$.

\section{Microbial diversity}

A total of 79,049 high-quality sequence reads were generated from Illumina MiSeq sequencing of V4 region on 16S rDNA in six camel rumen samples with an average of $13,175 \pm 1818$ reads per sample (mean \pm standard error). Total sequence reads in the barley straw fed group were 34,302 with a mean of $11,434 \pm 1841$; also, the total sequence reads in the
Egyptian clover hay fed group were 44,747 with a mean $14,915 \pm 3180$ sequence per sample. The number of ASVs and alpha diversity indices was higher in the group fed clover hay compared to the group fed barley straw without significant difference (Table-4).

\section{Analysis of bacterial community}

The taxonomic analysis of the bacterial community in the rumen of camels under investigation revealed 12 bacterial phyla (Table-5). The bacterial community in the current study was dominated by phylum Bacteroidetes (70.4\%) and Firmicutes $(23.6 \%)$. Other phyla that made up more than $1 \%$ were Proteobacteria $(1.6 \%)$, Spirochaetes $(1.7 \%)$, and Tenericutes $(1.5 \%)$. Bacterial phyla that represented $<1 \%$ were Cyanobacteria $(0.2 \%)$, Fibrobacteres $(0.6 \%)$, and Planctomycetes $(0.2 \%)$ (Table-5). Bacterial phyla observed only in the barley straw fed camel group were Verrucomicrobia, Kiritimatiellaeota, and Lentisphaerae. Moreover, the phylum Elusimicrobia was found only in the Egyptian clover hay fed group (Table-5).

Forage type affected the relative abundances of the bacterial phyla. Phylum Bacteroidetes was significantly higher $(p<0.05)$ in the camel group fed Egyptian clover hay compared to the camel group fed barley straw. On the family level, the members of phylum Bacteroidetes were affiliated mainly to the family Prevotellaceae, Rikenellaceae, and unclassified Bacteroidales (Table-6). Family Prevotellaceae was predominated by genus Prevotella that was significantly higher $(\mathrm{p}<0.05)$ in the Egyptian clover hay fed group compared to the barley straw fed group. Member of family Rikenellaceae was assigned mainly to $R C 9$ gut group that was higher

Table-2: Total feed intake and roughage feed intake of camels fed different forage types.

\begin{tabular}{|c|c|c|c|c|c|c|c|}
\hline \multirow[t]{2}{*}{ Item } & \multicolumn{2}{|c|}{ FS } & \multicolumn{2}{|c|}{$\mathbf{F H}$} & \multirow[t]{2}{*}{ Overall mean } & \multirow[t]{2}{*}{ SEM } & \multirow[t]{2}{*}{ p-value } \\
\hline & Mean & SE & Mean & SE & & & \\
\hline \multicolumn{8}{|c|}{ Forage feed intake $\mathrm{g} / \mathrm{kg}^{0.75}$} \\
\hline DMI & 33 & 0.57 & 33.7 & 0.5 & 33.35 & 0.36 & 0.401 \\
\hline CPI & 1.55 & 0.028 & 4.9 & 0.07 & 3.2 & 0.75 & $<0.0001$ \\
\hline NDFI & 22.2 & 0.36 & 18.8 & 0.3 & 20.5 & 0.8 & 0.002 \\
\hline \multicolumn{8}{|c|}{ Total feed intake $\mathrm{g} / \mathrm{kg}^{0.75}$} \\
\hline DMI & 46.2 & 0.57 & 46.9 & 0.47 & 46.5 & 0.36 & 0.401 \\
\hline CPI & 3.5 & 0.03 & 6.8 & 0.07 & 5.14 & 0.75 & 0.0001 \\
\hline NDFI & 29.2 & 0.36 & 25.8 & 0.29 & 27.5 & 0.8 & 0.002 \\
\hline
\end{tabular}

$\mathrm{SE}=$ Standard error, $\mathrm{DMI}=$ Dry matter intake, $\mathrm{CPI}=$ Crude protein intake, NDFI=Neutral detergent fiber intake,

$\mathrm{SEM}=$ Standard error of the mean, $\mathrm{FS}=$ barley straw, $\mathrm{FH}=$ Egyptian clover hay

Table-3: Rumen fermentation parameters and bacterial population in the rumen of camels fed different forage types.

\begin{tabular}{|c|c|c|c|c|c|c|c|}
\hline \multirow[t]{2}{*}{ Paramter } & \multicolumn{2}{|c|}{ FS } & \multicolumn{2}{|c|}{$\mathbf{F H}$} & \multirow[t]{2}{*}{ Overall mean } & \multirow[t]{2}{*}{ SEM } & \multirow[t]{2}{*}{ p-value } \\
\hline & Mean & SE & Mean & SE & & & \\
\hline $\mathrm{PH}$ & 6.7 & 0.05 & 6.3 & 0.05 & 6.5 & 0.09 & 0.008 \\
\hline Ammonia, mg/dL & 11.7 & 1.4 & 45.7 & 4.06 & 28.7 & 7.8 & 0.001 \\
\hline Volatile fatty acids, meq/dL & 15.7 & 2.3 & 26.6 & 0.33 & 21.16 & 2.6 & 0.01 \\
\hline Acetic, \% & 63.5 & 0.7 & 68 & 3.5 & 65.75 & 1.9 & 0.328 \\
\hline Propionic, \% & 26.2 & 0.7 & 22.6 & 1.45 & 24.4 & 1.06 & 0.097 \\
\hline Butyric, \% & 10.3 & 0.3 & 9.3 & 2.3 & 9.8 & 1.07 & 0.693 \\
\hline Bacterial population* & 7.6 & 0.1 & 6 & 0.28 & 6.8 & 0.38 & 0.006 \\
\hline
\end{tabular}

*Bacterial population=Log10 copies/ $\mu$ L DNA. SE=Standard error, FS=barley straw, FH=Egyptian clover hay

Veterinary World, EISSN: 2231-0916 
Available at www.veterinaryworld.org/Vol.15/January-2022/6.pdf

Table-4: Alpha diversity metrics of microbial communities in the rumen of camels fed different forages.

\begin{tabular}{|c|c|c|c|c|c|c|c|}
\hline \multirow[t]{2}{*}{ Alpha diversity indices } & \multicolumn{2}{|c|}{ FS } & \multicolumn{2}{|c|}{ FH } & \multirow[t]{2}{*}{ Overall mean } & \multirow[t]{2}{*}{ SEM } & \multirow[t]{2}{*}{ p-value } \\
\hline & Mean & SE & Mean & SE & & & \\
\hline Observed amplicon sequence variants & 531.7 & 76.32 & 1049 & 214.3 & 790.3 & 154 & 0.085 \\
\hline Chao1 & 532.36 & 76.75 & 1051 & 214.7 & 791.7 & 154.4 & 0.085 \\
\hline Shannon & 5.97 & 0.13 & 6.34 & 0.2 & 6.2 & 0.13 & 0.219 \\
\hline InvSimpson & 328.24 & 44.91 & 402.7 & 59.3 & 365.5 & 37.2 & 0.374 \\
\hline
\end{tabular}

$\mathrm{SE}=$ Standard error, $\mathrm{SEM}=$ Standard error of the mean, $\mathrm{FS}=$ barley straw, $\mathrm{FH}=$ Egyptian clover hay

Table-5: The relative abundances (\%) of bacterial phyla in the rumen of camels fed different forages.

\begin{tabular}{|c|c|c|c|c|c|c|c|}
\hline \multirow[t]{2}{*}{ Phylum } & \multicolumn{2}{|c|}{ FS } & \multicolumn{2}{|c|}{$\mathbf{F H}$} & \multirow[t]{2}{*}{ Overall mean } & \multirow[t]{2}{*}{ SEM } & \multirow[t]{2}{*}{ p-value } \\
\hline & Mean & SE & Mean & SE & & & \\
\hline Bacteroidetes & 53.45 & 3.04 & 87.4 & 0.96 & 70.4 & 7.7 & $<0.0001$ \\
\hline Cyanobacteria & 0.17 & 0.003 & 0.26 & 0.045 & 0.2 & 0.03 & 0.129 \\
\hline Firmicutes & 38.87 & 3.5 & 8.28 & 0.28 & 23.6 & 7.02 & 0.001 \\
\hline Fibrobacteres & 0.7 & 0.2 & 0.48 & 0.15 & 0.6 & 0.13 & 0.439 \\
\hline Planctomycetes & 0.25 & 0.06 & 0.15 & 0.03 & 0.2 & 0.03 & 0.196 \\
\hline Proteobacteria & 2.5 & 0.44 & 0.64 & 0.32 & 1.6 & 0.5 & 0.026 \\
\hline Spirochaetes & 1.4 & 0.45 & 2.1 & 0.5 & 1.7 & 0.35 & 0.382 \\
\hline Tenericutes & 2.2 & 0.16 & 0.8 & 0.2 & 1.5 & 0.32 & 0.007 \\
\hline Verrucomicrobia & 0.07 & 0 & 0 & 0 & 0 & 0 & ND \\
\hline Kiritimatiellaeota & 0.22 & 0 & 0 & 0 & 0 & 0 & ND \\
\hline Lentisphaerae & 0.12 & 0 & 0 & 0 & 0 & 0 & ND \\
\hline Elusimicrobia & 0 & 0 & 0.09 & 0 & 0 & 0 & ND \\
\hline
\end{tabular}

$\mathrm{ND}=$ Non-determined, $\mathrm{SEM}=$ Standard error of the mean, $\mathrm{FS}=$ barley straw, FH=Egyptian clover hay

Table-6: The relative abundances (\%) of bacterial families and genera in the rumen of camels fed different forages.

\begin{tabular}{|c|c|c|c|c|c|c|c|}
\hline \multirow[t]{2}{*}{ Family and genus } & \multicolumn{2}{|c|}{ FS } & \multicolumn{2}{|c|}{ FH } & \multirow[t]{2}{*}{ Overall mean } & \multirow[t]{2}{*}{ SEM } & \multirow[t]{2}{*}{ p-value } \\
\hline & Mean & SE & Mean & SE & & & \\
\hline \multicolumn{8}{|l|}{ Phylum: Bacteroidetes } \\
\hline Family Prevotellaceae & 26.9 & 3.5 & 48.8 & 1.5 & 37.9 & 5.2 & 0.005 \\
\hline Prevotella & 22.3 & 3.98 & 39.9 & 1.9 & 31.1 & 4.4 & 0.017 \\
\hline Rikenellaceae_RC9_gut_group & 15.3 & 1.8 & 11.5 & 0.17 & 13.4 & 1.17 & 0.166 \\
\hline Unclassified__Bacteroidales & 11.1 & 0.4 & 27.07 & 1.1 & 19.1 & 3.6 & $<0.0001$ \\
\hline \multicolumn{8}{|c|}{ Phylum: Firmicutes, family: Lachnospiraceae } \\
\hline Family Lachnospiraceae & 5.3 & 1.2 & 1.2 & 0.39 & 3.3 & 1.07 & 0.032 \\
\hline Butyrivibrio & 1.1 & 0.19 & 0.2 & 0.04 & 0.7 & 0.2 & 0.012 \\
\hline Acetitomaculum & & & 0.35 & & & & ND \\
\hline Moryella & & & 0.35 & & & & ND \\
\hline Lachnoclostridium & 0.65 & & & & & & ND \\
\hline \multicolumn{8}{|l|}{ Phylum: Firmicutes, Family_XIII } \\
\hline Anaerovorax & 1.3 & 0.2 & 0.17 & 0.02 & 0.7 & 0.26 & 0.041 \\
\hline Mogibacterium & 0.08 & & & & & & \\
\hline \multicolumn{8}{|c|}{ Phylum: Firmicutes, family: Ruminococcaceae } \\
\hline Family Ruminococcaceae & 16.9 & 2.1 & 5.3 & 0.5 & 11.1 & 2.8 & 0.006 \\
\hline Papillibacter & 3.52 & 0.09 & 0.7 & 0.22 & 2.11 & 0.63 & $<0.0001$ \\
\hline Ruminococcus & 1.01 & 0.09 & 1.48 & 0.18 & 1.24 & 0.14 & 0.091 \\
\hline Saccharofermentans & 2.06 & 0.11 & 0.27 & 0.08 & 1.17 & 0.4 & $<0.0001$ \\
\hline Unclassified_Ruminococcaceae & 3.3 & & & & & & ND \\
\hline \multicolumn{8}{|l|}{ Phylum: Firmicutes, other families } \\
\hline Christensenellaceae_R-7_group & 5.5 & & & & & & ND \\
\hline Lactobacillaceae_Lactobacillus & & & 0.05 & & & & ND \\
\hline Erysipelotrichaceae_UCG-004 & & & 1.45 & & & & ND \\
\hline $\begin{array}{l}\text { Acidaminococcaceae } \\
\text { Succiniclasticum }\end{array}$ & 7.5 & & & & & & ND \\
\hline Clostridiales_vadinBB60_group & & & 6.25 & & & & ND \\
\hline \multicolumn{8}{|l|}{ Phylum: Spirochaetes } \\
\hline Treponema_2 & 0.66 & 0.25 & 1.04 & 0.44 & 0.85 & 0.24 & 0.503 \\
\hline Sphaerochaeta & 0.9 & 0.2 & 0.95 & 0.17 & 0.93 & 0.12 & 0.873 \\
\hline \multicolumn{8}{|l|}{ Phylum: Tenericutes } \\
\hline Anaeroplasma & & & 0.49 & & & & ND \\
\hline
\end{tabular}

$\mathrm{ND}=$ Non-determined, $\mathrm{SE}=$ Standard error, $\mathrm{FS}=$ barley straw, $\mathrm{FH}=$ Egyptian clover hay 
in the barley straw fed than the Egyptian clover hay fed group without significant difference. Unclassified Bacteroidales were significantly higher $(p<0.05)$ in the Egyptian clover hay fed group than the barley straw fed group (Table-6). The relative abundance of phylum Firmicutes was significantly higher $(\mathrm{p}<0.05)$ in the barley straw fed group than the Egyptian clover hay fed group. The members of this phylum were assigned mainly to the family Lachnospiraceae, Ruminococcaceae, and Family_XIII. Family Lachnospiraceae was significantly prevalent $(p<0.05)$ in the barley straw fed group than in the Egyptian clover hay fed group; this family was dominated by genus Butyrivibrio that followed the same trend. In addition, some genera were observed exclusively in a specific group, such as Acetitomaculum and Moryella that were found only in the Egyptian clover hay fed group; also, genus Lachnoclostridium was found only in the group, the barley straw fed group (Table-6).

The relative abundance of family Ruminococcaceae was significantly higher $(\mathrm{p}<0.05)$ in the barley straw fed group than in the Egyptian clover hay fed group. In addition, the family members were assigned mainly to genus Papillibacter and Saccharofermentans that were higher in the barley straw fed group, and genus Ruminococcus that was higher in the Egyptian clover hay fed group. Uncultured_Ruminococcaceae was observed only in the barley straw fed group. Some families within phylum Firmicutes were observed in a specific group, including family Lactobacillaceae that was assigned to genus Lactobacillus, which was observed in the Egyptian clover hay fed group only. In addition, family Acidaminococcaceae that was affiliated to genus Succiniclasticum was observed only in the barley straw fed group. Phylum Spirochaetes was higher in the Egyptian clover hay fed group and was assigned to genus Treponema and Sphaerochaeta that were higher in the Egyptian clover hay fed group. The members of phylum Fibrobacteres, Planctomycetes, and Proteobacteria were higher in the barley straw fed group and members of phylum Cyanobacteria were higher in the Egyptian clover hay fed group.

\section{The production of lignocellulolytic enzymes Xylanase production}

The anaerobic bacteria in the rumen of dromedary camels under different forage types were tested for their ability to produce xylanase enzymes (in vitro) by incubating rumen samples in anaerobic bacterial media containing birchwood xylan for $48 \mathrm{~h}$. It could be noticed that higher xylanase production was associated with rumen samples collected from camels fed Egyptian clover hay fed $(388.7 \pm 58.3 \mathrm{mU} / \mathrm{mL})$ than camels fed barley straw fed $(165.7 \pm 6.6 \mathrm{mU} / \mathrm{mL})$ with a significant difference $(\mathrm{p}<0.05)$.

\section{Cellulase production}

In this study, rumen samples were inoculated into bacterial media containing different cellulose sources, $\mathrm{FP}, \mathrm{WS}$, and $\mathrm{AH}$, for $48 \mathrm{~h}$. Cellulase production varied according to the camel group and cellulose source. Maximum cellulase production was obtained when rumen samples of the barley straw fed group were inoculated into a bacterial medium supplemented with $\mathrm{AH}$ (Table-7). Pillai's trace multivariate and Tukey tests were used to assess the significance of differences in cellulase production between the camel groups (barley straw fed and Egyptian clover hay fed) and cellulose sources (FP, $\mathrm{WS}$, and $\mathrm{AH}$ ), and it was observed that the difference between the camel groups was non-significant. However, the effect of cellulose sources on cellulase production was significant $(p<0.05)$ and the interaction between the camel group and cellulose source was significant $(p<0.05)$. The t-independent test was used to examine the cellulase production between the camel groups using the cellulose sources separately and the results revealed that the differences in cellulase production between the camel groups were significant $(\mathrm{p}<0.05)$.

\section{Principal component analysis}

Principal component analysis was conducted based on the value of rumen $\mathrm{pH}$, ammonia, total VFA, enzymes productions, microbial diversity indices, and the relative abundances of bacterial groups. The result revealed that the samples were separated based on forage source (Figure-1).

\section{Discussion}

Understanding the regulations of rumen microbiota and their fibrolytic activities under different feeding regimes is the cornerstone to improving rumen fermentation and animal productivity [26,41]. This study was conducted to evaluate the effect of forage type on the rumen fermentation, and composition and diversity of rumen bacteria and their cellulolytic and xylanolytic activities. Two types of forages were fed to the camels under investigation, barely straw and Egyptian clover hay. The Egyptian clover is commonly used in animal feeding in Egypt and is considered as a high nutritive value fodder regarding the protein and carbohydrates

Table-7: Cellulase (endo-cellulase) activity $(\mathrm{mU} / \mathrm{mL})(\mathrm{mean} \pm \mathrm{SD})$ of rumen bacterial community of the dromedary camel fed different forages using different cellulose sources.

\begin{tabular}{|c|c|c|c|c|c|c|c|}
\hline \multirow[t]{2}{*}{ Cellulose source } & \multicolumn{2}{|c|}{ FS } & \multicolumn{2}{|c|}{$\mathbf{F H}$} & \multirow[t]{2}{*}{ Overall mean } & \multirow[t]{2}{*}{ SEM } & \multirow[t]{2}{*}{ p-value } \\
\hline & Mean & SE & Mean & SE & & & \\
\hline Filter paper & 146.34 & 34.35 & 18.8 & 2.2 & 82.5 & 32.4 & 0.053 \\
\hline Wheat straw & 219.9 & 113.9 & 59.6 & 18.7 & 139.8 & 62.8 & 0.017 \\
\hline Alfalfa hay & 1090.1 & 210.05 & 305.5 & 7.8 & 697.8 & 199.02 & 0.001 \\
\hline
\end{tabular}

$\mathrm{SE}=$ Standard error, SEM=Standard error of the mean, FS=barley straw, FH=Egyptian clover hay 


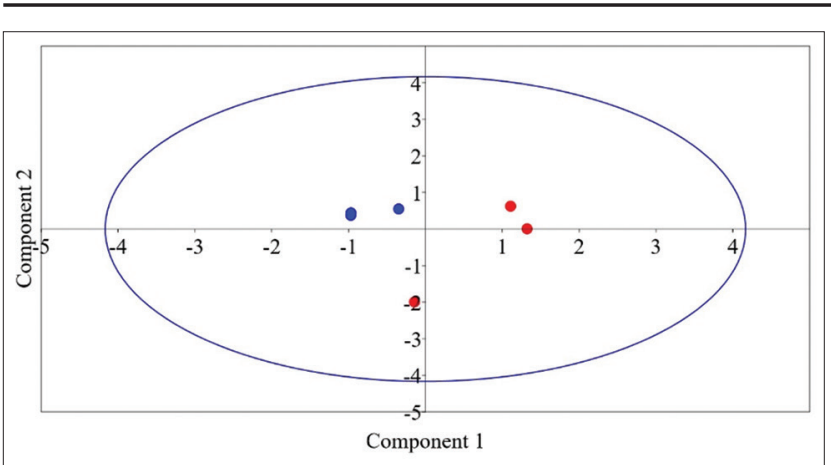

Figure-1: Principal component analysis of rumen bacterial community based on Bray-Curtis dissimilarity in the rumen of camels fed different forage types. The blue circles for camels fed barley straw and red triangle for camel fed clover hay.

contents [7]. The chemical composition of Egyptian clover hay and CFM was in the ranges that were reported by Rabee et al. [3,12] (Table-1). Barley straw fed is abundant lignocellulosic biomass worldwide and it has high-fiber and low-protein contents [42]. The chemical composition of barley straw fed was in the range indicated by the previous studies $[43,44]$. Liu et al. [45] explained that higher NDF content in straw results in slow degradability in the rumen.

\section{Feed intake and rumen fermentation}

Camels in this study offered free forage and the values of DMI were indicated in the previous studies on camels (Table-2) [46,47]. Forage type did not affect the DMI, which was supported by the previous studies on cattle $[11,48]$. In the same time, CPI and NDFI were affected by forage type, which agrees with Farid et al. [9]. Egyptian clover hay contains higher CP; while barley straw fed has higher NDF that explains the differences in $\mathrm{CPI}$ and NDFI. Lower rumen $\mathrm{pH}$ was linked to higher total VFA production in the Egyptian clover hay fed group that could be explained by the availability of soluble carbohydrates in clover hay compared to the barley straw [49-51]. The higher production of rumen ammonia in the Egyptian clover hay fed group that fed Egyptian clover hay is illustrated by higher CPI (Table-3) [52,53]. Wang et al. [48] compared the effect of different forage types on the feed intake, rumen fermentation in cows. They found that DMI was not affected and total VFA was higher in the group fed hay compared to the groups fed corn stover or rice straw that supports our findings.

The concentrations of acetic, propionic, and butyric acids in the current study were in the range observed by Dadvar et al. [54] for camels fed different forage plants. Camels fed barely straw showed lower acetic acid concentration (Table-3); a similar finding was obtained by Xu et al. [11]; and Zhang et al. [51] indicated that the inclusion of middle-quality forage such as Leymus chinensis in the animal diet increased the total VFA and acetic acid production.

\section{Rumen bacterial community}

Forage type did not affect the microbial diversity significantly (Table-5); this finding was also indicated by Hinsu et al. [22] in camels fed different forages. The majority of rumen bacteria in the current study were affiliated to phylum Bacteroidetes and Firmicutes that were affected by forage type (Tables-6 and 7), which was also indicated by the previous studies on camel and cattle [3,7,22,51]. Most of the phylum Bacteroidetes was assigned to genus Prevotella that showed higher representation in animals fed Egyptian clover hay fed; a similar result was obtained by the previous studies $[22,45,51]$ on cattle and camel fed different forages. Zhang et al. [51] reported that the prevalence of Prevotella in the rumen indicates the importance of this genus in rumen fermentation. This genus is involved in the degradation of different substrates in the rumen, including protein, xylan, pectin, and starch [7,45,51], illustrating the greater relative abundance in the Egyptian clover hay fed group that fed Egyptian clover hay that provides different growth substrates. Liu et al. [45] reported that Prevotella was correlated positively with protein content; therefore, it showed higher presentation with Egyptian clover hay fed group in the current study. Genus RC9 gut group within phylum Bacteroidetes is highly specialized in lignocellulose degradation, which demonstrates the high representation in the barley straw fed group, fed low-quality forage $[3,22,55]$.

Members of phylum Firmicutes were dominated by Butyrivibrio, Papillibacter, Ruminococcus, and Saccharofermentans that agree with the previous studies [45,56-58]. Genus Butyrivibrio and Ruminococcus are polysaccharide-degrading bacteria [45]. Papillibacter genus was previously found in a high proportion in cattle fed corn stover, which supports our results [51], and could indicate that this genus is involved in fiber digestion [59]. Furthermore, genus Succiniclasticum can degrade fiber and cellobiose [58], and was isolated from the rumen of animals fed grass silage and convert succinate to propionate [60], which might illustrate the presence of this genus in the barley straw fed group only and support the higher propionate in the barley straw fed group. Saccharofermentans is involved in polysaccharides degradation and produces acetate and propionate [61] explaining the higher proportion of this genus in the barley straw fed group.

Genus Fibrobacteres is specialized in cellulose degradation and was positively associated with higher NDF in animal diet $[7,17,45,51]$, explaining its higher representation in the barley straw fed group that was fed barley straw fed. Phylum Spirochaetes was dominated by genus Treponema that was higher in the barley straw fed group. Rabee et al. [7] indicated that Treponema is fiber-associated bacteria and has potential fibrolytic activities, which ensure our findings. The results showed that the bacterial community was dominated by genus Fibrobacteres, Prevotella, RC9_gut_group, Butyrivibrio, Papillibacter, Ruminococcus, Saccharofermentans, Sphaerochaeta, and Treponema, which are consistent with the previous studies [45,56-58]. Furthermore, these findings 
indicated the importance of these genera in the utilization of forage in the rumen $[45,57]$. Liu et al. [45] studied the degradability and colonization of rice straw and hay by rumen bacteria in cows and concluded that physical structure and chemical characteristics are the main determiners of microbial colonization; also, forage type affected the relative abundance of colonizing bacterial genera, wherever Prevotella was higher in alfalfa; Fibrobacteres and unclassified Ruminococcaceae were higher in rice straw; these findings support our findings. A higher proportion of the bacterial community in this study was found unclassified, including unclassified Bacteroidales and unclassified Ruminococcaceae; and these bacteria were affected by the forage type [7,22,51]. Unclassified Bacteroidales were higher in the Egyptian clover hay fed group; while, unclassified Ruminococcaceae were found only in the barley straw fed group; a similar result was found by Zhang et al. [51]. Stiverson et al. [62] reported that unclassified bacteria might have a role in biohydrogenation in the rumen, which indicates that forage type affects the composition of fatty acids [51]. Liu et al. [45] indicated that unclassified bacteria were associated with NDF content indicating their role in degrading low-quality forage.

\section{Enzymes production}

This study gets insights into the ability of anaerobic bacteria in the rumen of camels to produce xylanase and cellulase using birchwood xylan and different cellulose sources, FP, WS, and AH. Cellulase and xylanase production is inducible as it depends on various factors such as inoculum size, $\mathrm{pH}$ value, temperature, medium additives, fermentation time, and growth substrate $[12,23,26,28,63]$. Xylanase and cellulase productions were in the range indicated by similar studies [64-66] for rumen bacteria. On the other hand, the anaerobic bacterial community in this study produced more xylanase and cellulase than the aerobic fungi [67] and anaerobic rumen fungi of the camel gut [26]. Moreover, cellulase production was similar to the production of some commercial bacterial strains such as Escherichia coli [68] and cellulolytic bacterial consortium [69], highlighting the higher cellulolytic activities of rumen bacteria in camel. Cellulase production varied greatly between cellulose sources, and the highest cellulase production $(1090 \mathrm{mU})$ was observed by anaerobic bacteria incubated in $\mathrm{AH}$ media supplemented by alfalfa hay, which is in agreement with similar studies $[23,24,63]$. The variation in cellulase production among the substrates in the current study could be attributed to the variation in the composition of the bacterial community associated with the carbon sources [29].

Animal diet affected xylanase and cellulase productions and higher xylanase production was observed by rumen bacteria of the Egyptian clover hay fed group. Higher cellulase production was observed with the bacterial culture of the barley straw fed group that was inoculated in AH media. The feeding system, including diet composition and feeding plan, is the primary determiner of the composition of rumen microbial communities [70]. For example, high-fiber diets stimulate the cellulolytic and hemicellulolytic microbes; while, starch and sugars are the major fermentation components of concentrate-based diets; thus, favoring the amylolytic microbes [71]. Our results indicated that forage type affected the composition of rumen bacteria. For example, the Egyptian clover hay fed group showed higher Prevotella that have xylanolytic activities $[7,45]$ and Ruminococcus that have cellulolytic and xylanolytic activities $[23,45]$. These findings explain the higher xylanase production associated with the Egyptian clover hay fed group. Meanwhile, the camel group barley straw fed showed higher relative abundances of cellulolytic bacteria such as Fibrobacter, RC9_gut_group, Butyrivibrio, Papillibacter, Saccharofermentans, and Treponema [45,56-58] that explain higher cellulase production in the barley straw fed group. Samsudin et al. [29] inoculated rumen fluid from dromedary camels into anaerobic bacterial media enriched with three different fiber sources, including cotton thread, FP, and NDF from lucerne hay, and the results showed that the fiber type influenced the composition of bacterial community that grows in the fiber-enriched medium.

Moreover, members related to the phylum Firmicutes were dominant and some of the bacteria involved in the fiber digestion were assigned to Fibrobacteres. Thus, the higher cellulase and xylanase production associated with bacterial community of the Egyptian clover hay and barley straw fed camel groups could be attributed to the high proportion of fibrolytic bacteria in the original rumen content. This study highlights the rumen content of camels, is a promising source for lignocellulolytic enzymes and lignocellulolytic bacteria for commercial production of cellulase and xylanase enzymes.

The interaction between the anaerobic bacterial community leads to effective degradation of cellulose as the fiber degradation requires different types of cellulases and xylanases, which could not be produced together by many bacterial strains; therefore, it is challenging to utilize cellulose by pure bacterial cultures [72]. Thus, using mixed bacterial community in enzyme production is an effective technique to promote the utilization of poor-quality forages. The results of PCA explained that forage type affected chemical composition of animal diet and CPI and NDFI. Consequently, the rumen fermentation and composition of rumen bacteria were affected. Moreover, the cellulolytic and xylanolytic activities of rumen bacteria were affected.

Camel is well adapted to desert harsh conditions by unique grazing behavior and morphophysiology of the digestive system [73]. In addition, the retention time of ingested feed is longer in camel rumen than other ruminants, which improves the efficiency 
of plant biomass fermentation and that might explain the prevalence of fibrolytic and potential fibrolytic microorganisms in the camel rumen compared to other ruminants [7]. For instance, camel rumen contains higher relative abundances of $R C 9$ gut group, Fibrobacteres, and Ruminococcaceae than sheep and cattle $[74,75]$, which highlight the camel rumen as a potential source of fibrolytic microorganisms or their enzymes for commercial applications.

\section{Conclusion}

This study expands our knowledge regarding the effect of forage type on rumen fermentation, rumen microbiota, and metabolic capabilities of rumen bacteria. Egyptian clover hay increased rumen ammonia and total VFA and barely straw maintained higher rumen $\mathrm{pH}$. The proportions of some polysaccharide-degrading bacteria were increased by including Egyptian clover in the camel diet. Egyptian clover hay is suitable forage for camel fed under intensive production; however, the barley straw could be suitable alternative. This study could be a base to design a feeding plan for camels under intensive production.

\section{Authors' Contributions}

AER: Designed the study, performed the experiments, analyzed the data, prepared figures and tables, wrote and reviewed drafts of the manuscript, and approved the final draft.

\section{Acknowledgments}

The author is grateful to the staff of Maryout Research Station, Desert Research Center, Cairo, Egypt, for providing the necessary facilities for the study. The author did not receive any funds for this study.

\section{Competing Interests} interests.

The author declares that he has no competing

\section{Publisher's Note}

Veterinary World remains neutral with regard to jurisdictional claims in published institutional affiliation.

\section{References}

1. Wako, G., Tadesse, M. and Angassa, A. (2017) Camel management as an adaptive strategy to climate change by pastoralists in Southern Ethiopia. Ecol. Process, 6: 26.

2. Iqbal, A. and Khan, B.B. (2001) Feeding behaviour of camel. Pak. J. Agric. Sci., 38(3-4): 58-63.

3. Rabee, A.E., Forster, R.J., Elekwachi, C.O., Kewan, K.Z., Sabra, E., Mahrous, H.A., Khamiss, O.A. and Shawket, S.M. (2020a) Composition of bacterial and archaeal communities in the rumen of dromedary camel using cDNA-amplicon sequencing. Int. Microbiol., 23(2): 137-148.

4. Bornstein, S. (1990) The ship of the desert. The dromedary camel (Camelus dromedarius), a domesticated animal species well adapted to extreme conditions of aridness and heat. Rangifer, 10(3): 231-236.

5. Faye, B. (2013) Camel farming sustainability: The challenges of the camel farming system in the $\mathrm{XXI}^{\text {th }}$ century. J. Sustain. Dev., 6(12): 74-82.

6. Faye, B. (2016) The camel, new challenges for a sustainable development. Trop. Anim. Health Prod., 48(4): 689-692.

7. Rabee, A.E., Forster, R., Elekwachi, C., Sabra, E. and Lamara, M. (2020b) Comparative analysis of the metabolically active microbial communities in the rumen of dromedary camels under different feeding systems using total rRNA sequencing. PeerJ, 8: e10184.

8. Kadim, I.T., Mahgoub, O. and Purchas, R.W. (2008) A review of the growth, and of the carcass and meat quality characteristics of the one-humped camel (Camelus dromedaries). Meat Sci., 80(3): 555-569.

9. Farid, M.F.A., Abdel-Wahed, A.M., Shawket, S.M. and Hassan, N.I. (2010) Diet selection, feed intake capacity and performance of growing female camels: Effects of type of roughage and level of concentrates offered. J. Am. Sci., 6(11): 317-326.

10. Faraz, A., Younas, M., Waheed, A., Tauqir, N.A., Nabeel, M.S., Mirza, R.H., Ishaq, H.M. and Khan, N.U. (2020) Growth management of Marecha camel (Camelus dromedarius) in feedlot under desert conditions. Adv. Anim. Vet. Sci., 8(11): 1114-1119.

11. Xu, J., Hou, Y., Yang, H., Shi, R., Wu, C., Huo, Y. and Zhao, G. (2014) Effects of forage sources on rumen fermentation characteristics, performance, and microbial protein synthesis in mid lactation cows. Asian Australas. J. Anim. Sci., 27(5): 667-673.

12. Rabee, A.E., Forster, R.J., Elekwachi, C.O., Kewan, K.Z., Sabra, E.A., Shawket, S.M., Mahrous, H.A. and Khamiss, O.A. (2019) Community structure and fibrolytic activities of anaerobic rumen fungi in dromedary camels. $J$. Basic Microbiol., 59(1): 101-110.

13. Zhu, W., Fu, Y., Wang, B., Wang, C., Ye, J.A., Wu, Y.M. and Liu, J.X. (2013) Effects of dietary forage sources on rumen microbial protein synthesis and milk performance in early lactating dairy cows. J. Dairy Sci., 96(3): 1727-1734.

14. Gilbert, R.A., Townsend, E.M., Crew, K.S., Hitch, T.C.A., Friedersdorff, J.C.A., Creevey, C.J., Pope, P.B., Ouwerkerk, D. and Jameson, E. (2020) Rumen virus populations: Technological advances enhancing current understanding. Front. Microbiol., 11: 450.

15. Loor, J.J., Elolimy, A.A. and McCann, J.C. (2016) Dietary impacts on rumen microbiota in beef and dairy production. Anim. Front., 6(3): 22-29.

16. Koike, S. and Kobayashi, Y. (2009) Fibrolytic rumen bacteria: Their ecology and functions. Asian Australas. J. Anim. Sci, 22(1): 131-138.

17. Tajima, K., Aminov, R.I., Nagamine, T., Matsui, H., Nakamura, M. and Benno, Y. (2001) Diet-dependent shifts in the bacterial population of the rumen revealed with realtime PCR. Appl. Environ. Microbiol., 67(6): 2766-2774.

18. Lee, H.J., Jung, J.Y., Oh, Y.K., Lee, S.S., Madsen, E.L. and Jeon, C.O. (2012) Comparative survey of rumen microbial communities and metabolites across one Caprine and three Bovine groups, using bar-coded pyrosequencing and $1 \mathrm{H}$ nuclear magnetic resonance spectroscopy. Appl. Environ. Microbiol., 78(17): 5983-5993.

19. Kala, A., Kamra, D.N., Kumar, A., Agarwal, N., Chaudhary, L.C. and Joshi, C.G. (2017) Impact of levels of total digestible nutrients on microbiome, enzyme profile and degradation of feeds in buffalo rumen. PLoS One, 12(2): e0172051.

20. Gharechahi, J. and Salekdeh, G.H. (2018) A metagenomic analysis of the camel rumen's microbiome identifies the major microbes responsible for lignocellulose degradation and fermentation. Biotechnol. Biofuels, 11: 216.

21. Ameri, R., Laville, E., Potocki-VeÂronèse, G., Trabelsi, S., Mezghani, M., Elgharbi, F. and Bejar, S. (2018) Two new gene clusters involved in the degradation of plant cell wall from the fecal microbiota of Tunisian dromedary. PLoS One, 13(3): e0194621. 
22. Hinsu, A.T., Tulsani, N.J., Panchal, K.J., Pandit, R.J., Jyotsana, B., Dafale, N.A., Patil, N.V., Purohit, H.J., Joshi, C.G. and Jakhesara. S.J. (2021) Characterizing rumen microbiota and CAZyme profile of Indian dromedary camel (Camelus dromedarius) in response to different roughages. Sci. Rep., 11: 9400.

23. Ekinci, M.S., Özcan, N., ÖzkÖse, E. and Flint, H.J. (2001) A study on cellulolytic and hemicellulolytic enzymes of anaerobic rumen bacterium Ruminococcus flavefaciens strain 17. Turk. J. Vet. Anim. Sci., 25(5): 703-709.

24. Sadhu, S., Ghosh, P. K., Aditya, G. and Maiti, T.K. (2014) Optimization and strain improvement by mutation for enhanced cellulase production by Bacillus sp. (MTCC10046) isolated from cow dung. J. King Saud Univ. Sci., 26(4): 323-332.

25. Khatab, M.S.A., Abd El Tawab, A.M. and Fouad, M.T. (2017) Isolation and characterization of anaerobic bacteria from frozen rumen liquid and its potential characterization. Int. J. Dairy Sci., 12(1): 47-51.

26. Rabee, A.E., Forster, R. and Sabra, E.A. (2021) Lignocelluloytic activities and composition of bacterial community in the camel rumen. AIMS Microbiol., 7(3): 354-367.

27. Molina-Guerrero, C.E., de la Rosa, G., Castañeda, J.G., Sánchez, Y., Castillo-Michel, H., Valdez-Vazquez, I., Balcazar, E. and Salmerón, I. (2018) Optimization of culture conditions for production of cellulase by Stenotrophomonas maltophilia. Bioresources, 13(4): 8358-8372.

28. Sethi, S., Datta, A., Gupta, B.L. and Gupta, S. (2013) Optimization of cellulase production from bacteria isolated from soil. Int. Sch. Res. Notices, 2013: 985685.

29. Samsudin, A.A., Wright, A.D.G. and Al Jassim, R. (2012) Cellulolytic bacteria in the foregut of the dromedary camel (Camelus dromedarius). Appl. Environ. Microbiol., 78(24): 8836-8839.

30. AOAC. (1997) Association of Official Analytical Chemists Official Methods of Analysis. $16^{\text {th }}$ ed. AOAC, Arlington, VA, USA.

31. Van Soest, P.J., Robertson, J.B. and Lewis, B.A. (1991) Methods for dietary fibre, neutral detergent fibre and nonstarch polysaccharides in relation to animal nutrition. $J$. Dairy Sci., 74(10): 3583-3597.

32. Annison, E.F. (1954) Studies on the volatile fatty acids of sheep blood with special reference to formic acid. Biochem. J., 58(4): 670-680.

33. Walters, W., Hyde, E.R., Berg-Lyons, D., Ackermann, G., Humphrey, G., Parada, A., Gilbert, J.A., Jansson, J.K., Caporaso, J.G., Fuhrman, J.A., Apprill, A. and Knight, B. (2015) Improved bacterial 16S rRNA gene (V4 and V4-5) and fungal internal transcribed spacer marker gene primers for microbial community surveys. mSystems, 1(1): e00009-15.

34. Comeau, A.M., Douglas, G.M. and Langille, M.G.I. (2017) Microbiome helper: A custom and streamlined workflow for microbiome research. mSystems, 2(1): e00127-16.

35. Denman, S.E. and McSweeney, C.S. (2006) Development of a real-time PCR assay for monitoring anaerobic fungal and cellulolytic bacterial populations within the rumen. FEMS Microbiol. Ecol., 58(3): 572-582.

36. Callahan, B., McMurdie, P., Rosen, M., Han, A.W., Johnson, A.J.A. and Susan, P. (2016) DADA2: Highresolution sample inference from Illumina amplicon data. Nat. Methods, 13(7): 581-583.

37. Caldwell, D.R. and Bryant, M.P. (1966) Medium without rumen fluid for nonselective enumeration and isolation of rumen bacteria. J. Appl. Microbiol., 14(5): 794-801.

38. McSweeney, C.S., Denman, S.E. and Mackie, R.I. (2005) Rumen bacteria. In: Makkar H.P., McSweeney, C.S., editors. Methods in Gut Microbial Ecology for Ruminants. Springer, Dordrecht.

39. SPSS. (1999) Statistical Package for Social Science Release 15 , SPSS INC, Chicago, USA.
40. Hammer, Ø., Harper, D.A.T. and Ryan, P.D. (2001) PAST: Paleontological statistics software package for education and data analysis. Palaeontol. Electron, 4(1): 9.

41. Pope, P.B., Ouwerkerk, D. and Jameson, E. (2020) Rumen virus populations: Technological advances enhancing current understanding. Front. Microbiol., 11: 450.

42. Iroba, K.L., Tabil, L.G., Sokhansanj, S. and Dumonceaux, T. (2014) Pretreatment and fractionation of barley straw using steam explosion at low severity factor. Biomass Bioenergy, 66: 286-300.

43. Viljoen, M., Brand, T.S. and Hoffman, L.C. (2005) Differences in the chemical composition and digestibility of cereal hay and straw produced in a Mediterranean rainfall area of South Africa. S. Afr. J. Plant Soil, 22(2): 106-109.

44. Griffith, C.L., Ribeiro, G.O. Jr., Oba, M., McAllister, T.A. and Beauchemin, K.A. (2016) Fermentation of ammonia fiber expansion treated and untreated barley straw in a rumen simulation technique using rumen inoculum from cattle with slow versus fast rate of fiber disappearance. Front. Microbiol., 7: 1839.

45. Liu, J., Zhang, M., Xue, C., Zhu, W. and Mao, S. (2016) Characterization and comparison of the temporal dynamics of ruminal bacterial microbiota colonizing rice straw and alfalfa hay within ruminants. J. Dairy Sci., 99(12): 9668-9681.

46. Gihad, E.A., El-Gallad, T.T., Sooud, A.E., Farid, M.F.A. and Abou El-Nasr, H.M. (1989) Feed and water intake, digestibility and nitrogen utilization by camels compared to sheep and goats fed low protein desert by-products. Options Mediterr. Sémin., 2: 75-81.

47. Laameche, F., Chehma, A. and Faye, B. (2019) Effect of diet composition on dry matter intake of dairy she-camels. Trop. Anim. Health Prod., 51(8): 2513-2519.

48. Wang, B., Mao, S.Y., Yang, H.J., Wu, Y.M., Wang, J.K., Li, S.L., Shen, Z.M. and Liu, J.X. (2014) Effects of alfalfa and cereal straw as a forage source on nutrient digestibility and lactation performance in lactating dairy cows. J. Dairy Sci., 97(12): 7706-7715.

49. Karabulut, A., Ozcan, C., Kamalak, A. and Canbolat, Ö. (2006) Comparison of the nutritive value of a turkey native forage, tumbleweed hay (Gundelia tournefortii L.), wheat straw and alfalfa hay using in situ and in vitro measurements with sheep. Arch. Latin. Prod. Anim., 14(3): 78-83.

50. Pearson, R.A., Archibald, R.F. and Muirhead, R.H. (2006) A comparison of forage type and level of feeding on the digestibility and gastrointestinal mean retention time of dry forages given to cattle, sheep, ponies, and donkeys. $B r . J$. Nutr., 95(1): 88-98.

51. Zhang, R., Zhu, W., Zhu, W., Liu, J. and Mao, S. (2014) Effect of dietary forage sources on rumen microbiota, rumen fermentation and biogenic amines in dairy cows. $J$. Sci. Food Agric., 94(9): 1886-1895.

52. Hamchara, P., Chanjula, P., Cherdthong, A. and Wanapat, M. (2018) Digestibility, ruminal fermentation, and nitrogen balance with various feeding levels of oil palm fronds treated with Lentinus sajor-caju in goats. Asian Australas. J. Anim. Sci., 31(10): 1619-1626.

53. García-Rodríguez, J., Mateos, I., Saro, C., González, J.S., Carro, M.D. and Ranilla, M.J. (2020) Replacing forage by crude olive cake in a dairy sheep diet: Effects on ruminal fermentation and microbial populations in rusitec fermenters. Animals, 10(12): 2235

54. Dadvar, P., Mohammadabadi, T., Sari, M. and Fayazi, J. (2019) Investigation of rumen fermentation parameters and some blood metabolites of dromedary camels fed with $\mathrm{C}_{3}$ and $\mathrm{C}_{4}$ forages. Vet. Res. Forum, 10(3): 241-248.

55. Mackenzie, A.K., Naas, A.E., Kracun, S.K., Schuckel, J., Fangel, J.U., Agger, J.W., Willats, W.G., Eijsink, V.G. and Pope, P.B. (2015) A polysaccharide utilization locus from an uncultured bacteroidetes phylotype suggests ecological adaptation and substrate versatility. Appl. Environ. Microbiol., 81(1): 187-195. 
56. Piao, H., Lachman, M., Malfatti, S., Sczyrba, A., Knierim, B., Auer, M., Tringe, S.G., Mackie, R.I., Yeoman, C.J. and Hess, M. (2014) Temporal dynamics of fibrolytic and methanogenic rumen microorganisms during in situ incubation of switchgrass determined by $16 \mathrm{~S}$ rRNA gene profiling. Front. Microbiol., 5: 307.

57. Huws, S.A., Edwards, J.E., Creevey, C.J., Stevens, P.R., Lin, W., Girdwood, S., Pachebat, J.A. and KingstonSmith, A.H. (2016) Temporal dynamics of the metabolically active rumen bacteria colonising fresh perennial ryegrass. FEMS Microbiol. Ecol., 92(1): fiv137.

58. Du, C., Nan, X., Wang, K., Zhao, Y. and Xiong, B. (2019) Evaluation of the digestibility of steam-exploded wheat straw by ruminal fermentation, sugar yield and microbial structure in vitro. RSC Adv., 9: 41775-41782.

59. Mao, S.Y., Zhang, R.Y., Wang, D.S. and Zhu, W.Y. (2013) Impact of subacute ruminal acidosis (SARA) adaptation on rumen microbiota in dairy cattle using pyrosequencing. Anaerobe, 24: 12-9.

60. van Gylswyk, N.O. (1995) Succiniclasticum ruminis gen. nov., sp. Nov., a ruminal bacterium converting succinate to propionate as the sole energy-yielding mechanism. Int. J. Syst. Evol. Microbiol., 45(2): 297-300.

61. Xue, Y., Lin, L., Hu, F. Zhu, W. and Mao, S. (2020) Disruption of ruminal homeostasis by malnutrition involved in systemic ruminal microbiota-host interactions in a pregnant sheep model. Microbiome, 8: 138.

62. Stiverson, J., Morrison, M. and Yu, Z. (2011) Populations of select cultured and uncultured bacteria in the rumen of sheep and the effect of diets and ruminal fractions. Int. J. Microbiol., 2011: 750613.

63. Williams, A.G. and Withers, S.E. (1982) The production of plant cell wall polysaccharide-degrading enzymes by hemicellulolytic rumen bacterial isolates grown on a range of carbohydrate substrates. J. Appl. Microbiol., 52(3): 377-387.

64. Seo, J.K., Park, T.S., Kwon, I.H., Piao, M.Y., Lee, C.H. and Ha, J.K. (2013) Characterization of cellulolytic and xylanolytic enzymes of Bacillus licheniformis JK7 isolated from the rumen of a native Korean goat. Asian Australas. J. Anim. Sci., 26(1): 50-58.

65. Asem, D., Leo, V.V., Passari, A.K., Tonsing, M.V., Joshi, J.B., Uthandi, S., Hashem, A., Abd Allah, E.F. and Singh, B.P. (2017) Evaluation of gastrointestinal bacterial population for the production of holocellulose enzymes for biomass deconstruction. PLoS One, 12(10): e0186355.

66. Srivastava, S., Dafale, N.A., Jakhesara, S.J., Joshi, C.G., Patil, N.V. and Purohit, H.J. (2021) Unraveling the camel rumen microbiome through metaculturomics approach for agriculture waste hydrolytic potential. Arch. Microbiol., 203(1): 107-123.

67. Salmon, D.N.X., Spier, M.R., Soccol, C.R., Vandenberghe, L.P.S., Montibeller, V.W., Bier, M.C.J. and Faraco, V. (2014) Analysis of inducers of xylanase and cellulase activities production by Ganoderma applanatum LPB MR-56. Fungal Biol, 118(8): 655-662.

68. Mutreja, R., Das, D., Goyal, D. and Goyal, A. (2011) Bioconversion of agricultural waste to ethanol by SSF using recombinant cellulase from Clostridium thermocellum. Enzyme Res., 1: 1-6.

69. Poszytek, K., Ciezkowska, M., Sklodowska, A. and Drewniak, L. (2016) Microbial consortium with high cellulolytic activity (MCHCA) for enhanced biogas production. Front. Microbiol., 7: 324.

70. Henderson, G., Cox, F., Ganesh, S., Jonker, A., Young, W. and Janssen, P.J. (2015) Rumen microbial community composition varies with diet and host, but a core microbiome is found across a wide geographical range. Sci. Rep., 5: 14567.

71. Carberry, C.A., Kenny, D.A., Han, S., McCabe, M.S. and Waters, S.M. (2012) Effect of phenotypic residual feed intake and dietary forage content on the rumen microbial community of beef cattle. Appl. Environ. Microbiol., 78(14): 4949-4958.

72. Zhang, L., Chung, J., Jiang, Q., Sun, R., Zhang, J., Zhong, Y. and Ren, N. (2017) Characteristics of rumen microorganisms involved in anaerobic degradation of cellulose at various pH values. $R S C A d v$., 7: 40303-40310.

73. Kay, R.N.B. and Maloiy, M.O. (1989) Digestive secretions in camels. Options Méditerr. Sémin., 2: 83-87.

74. Wang, Q., Gao, X., Yang, Y., Zou, C., Yang, Y. and Lin, B. (2020) A comparative study on rumen ecology of water buffalo and cattle calves under similar feeding regime. Vet. Med. Sci., 6(4): 746-754.

75. Rabee, A.E., Kewan, K.Z., Sabra, E.A., El Shaer, H.M. and Lamara, M. (2021) Rumen bacterial community profile and fermentation in Barki sheep fed olive cake and date palm byproducts. PeerJ, 9: e12447. 